\title{
Müllerian inhibiting substance/anti-Müllerian hormone: A novel treatment for gynecologic tumors
}

\author{
Jang Heub Kim', David T. MacLaughlin², Patricia K. Donahoe ${ }^{2}$ \\ ${ }^{1}$ Department of Obstetrics and Gynecology, The Catholic University of Korea College of Medicine, Seoul, Korea; ${ }^{2}$ Pediatric Surgical Research \\ Laboratories, Massachusetts General Hospital, Harvard Medical School, Boston, MA, USA
}

Müllerian inhibiting substance (MIS), also called anti-Müllerian hormone (AMH), is a member of the transforming growth factor- $\beta$ super-family of growth and differentiation response modifiers. It is produced in immature Sertoli cells in male embryos and binds to MIS/AMH receptors in primordial Müllerian ducts to cause regression of female reproductive structures that are the precursors to the fallopian tubes, the surface epithelium of the ovaries, the uterus, the cervix, and the upper third of the vagina. Because most gynecologic tumors originate from Müllerian ductderived tissues, and since MIS/AMH causes regression of the Müllerian duct in male embryos, it is expected to inhibit the growth of gynecologic tumors. Purified recombinant human MIS/AMH causes growth inhibition of epithelial ovarian cancer cells and cell lines in vitro and in vitro via MIS receptor-mediated mechanism. Furthermore, several lines of evidence suggest that MIS/AMH inhibits proliferation in tissues and cell lines of other MIS/AMH receptor-expressing gynecologic tumors such as cervical, endometrial, breast, and in endometriosis as well. These findings indicate that bioactive MIS/AMH recombinant protein should be tested in patients against tumors expressing the MIS/AMH receptor complex, perhaps beginning with ovarian cancer because it has the worst prognosis. The molecular tools to identify MIS/AMH receptor expressing ovarian and other cancers are in place, thus, it is possible to select patients for treatment. An MIS/AMH ELISA exists to follow administered doses of MIS/AMH, as well. Clinical trials await the production of sufficient supplies of qualified recombinant human MIS/AMH for this purpose

Keywords: Mullerian tumor; Mullerian inhibiting substance type II receptor; Mullerian inhibiting substance; AntiMullerian hormone; Ovarian neoplasms

\section{Introduction}

During early mammalian development embryos possess the capacity to produce complete female and male reproductive tracts. The Müllerian ducts will become the upper third of the vagina, the cervix, uterus, Fallopian tubes and the outer lining of the ovaries. The Wolffian ducts become the seminal vesicles, vasa deferens and epididymides. These ductal systems grow adjacent to but independent of one another. Once the genetic sex of the embryo becomes known specific changes begin to occur. For example, at about 10 weeks gestation in human the undifferentiated gonads become either testes, under the control of the SRY gene [1] or ovaries. As gonads begin to differentiate one of the reproductive tract primordia is destroyed and the other proliferates and differentiates. In females, the lack of testosterone is sufficient to allow the Wolffian ducts to atrophy while in males the ablation of the Mül- lerian duct is more complex. The French anatomist Dr. Alfred Jost shed some very important light on the process in males over 65 years ago $[2,3]$. At that time it was believed that the key to normal prenatal sexual development was whether testes were present. The testosterone they secrete would both

Received: 2014.3.27. Revised: 2014.5.15. Accepted: 2014.5.15. Corresponding author: Patricia K. Donahoe

Pediatric Surgical Research Laboratories, Massachusetts General Hospital, Harvard Medical School, 185 Cambridge St., CPZN 6.220, Boston, MA 02114, USA

Tel: +1-617-724-1600 Fax: +1-617-726-5057

E-mail: pdonahoe@partners.org

Articles published in Obstet Gynecol Sci are open-access, distributed under the terms of the Creative Commons Attribution Non-Commercial License (http://creativecommons. org/licenses/by-nc/3.0/) which permits unrestricted non-commercial use, distribution, and reproduction in any medium, provided the original work is properly cited.

Copyright $\odot 2014$ Korean Society of Obstetrics and Gynecology 


\title{
Obstetrics \& Gynecology Science
}

\author{
Vol. 57, No. 5, 2014
}

stimulate the Wolffian ducts and destroy the Müllerian ducts. Professor Jost's experiments proved that testosterone alone was insufficient to the task because the gonadectomized embryos he treated with testosterone crystals had retained uteri at birth. He proposed that a "Müllerian inhibiting substance $(\mathrm{MIS})$ " now also called anti-Müllerian hormone $(\mathrm{AMH})$, is secreted from the newly formed testes and that it is the MIS/ $\mathrm{AMH}$ which causes the regression of the Müllerian ducts. It was later shown that regression is due mainly to apoptosis, autophagocytosis, disruption of basement membranes, and epithelial mesenchymal transformation of cells followed by migration of some of the cells toward the mesonephros [4-9].

\section{Müllerian inhibiting substance/anti- Müllerian hormone protein}

Over two decades after professor Jost's observation the source of MIS/AMH in males was identified as the Sertoli cells $[10,11]$ in rat $[12]$, bovine $[13,14]$ and human testis $[15,16]$. In addition, it was learned that MIS/AMH production is sexually dimorphic. MIS/AMH gene transcription is regulated in males by a number of factors including SF1, SOX 9 and WT-1 in utero but after birth androgens have been implicated in suppression of MIS/AMH expression [17-23] while there are data showing MIS/AMH can inhibit androgen synthesis as well [24-26]. MIS/ AMH is expressed in significant amounts only by males during fetal life but postnatally, both granulosa cells in the female and Sertoli cells in the male secrete MIS/AMH. In males serum MIS/ AMH levels remain high until puberty, dropping to basal levels, thereafter. Although MIS/AMH mRNA is detectable in ovaries shortly after birth [27] MIS/AMH is undetectable in serum until puberty where its levels reach those of adult males (Fig. 1) [28]. The detection of MIS/AMH in both sexes after birth [2931] suggested multifunctional roles for MIS/AMH. In females, MIS/AMH blocks meiosis II [32], inhibits ovarian granulosa cell division and progesterone production [33], and modulates follicular development [34]. Furthermore, MIS/AMH levels in follicular fluid are inversely correlated with granulosa cell proliferative index $[35,36]$. In males, MIS/AMH affects Leydig cell development and inhibits transcription of the steroidogenic enzyme, CYP17 $[24,25,37,38]$. Its stage-specific expression in seminiferous tubules implies a role in spermatogenesis [39]. Recent findings showing MIS/AMH and its receptor expression in pituitary and motor neurons indicate even more widespread non-Müllerian roles for MIS/AMH $[40,41]$. In fact, the prostate $[42,43]$, mammary gland $[44,45]$ and some of their cancers $[45,46]$ as well as ocular melanoma [47] are possible targets for MIS/AMH. The role MIS/AMH plays in these tissues is at present unknown.

MIS/AMH was purified from testicular secretions in vitro $[13,48,49]$ or protein extracts $[13,50-56]$ by conventional biochemical techniques $[13,48-56]$ and compositional analyses revealed it to be a $140 \mathrm{kDa}$ glycoprotein disulfide linked homo-dimer of approximately $15 \%$ carbohydrate by weight. MIS/AMH is cleaved into two fragments, most likely during the biosynthetic process before secretion by kex-like prohormone convertases.

Analyses of bovine CDNA and human genomic sequences revealed MIS/AMH to be weakly related to the transforming beta family of proteins with the most striking homology (28\%) residing in the carboxy-terminal domain $[55,56]$. The $2.8 \mathrm{~kb}$ human gene contains five exons and four introns and is located on the short arm of chromosome 19 [57]. The deduced protein sequence of the MIS/AMH monomer contains a 25 amino acid secretion specific signal peptide and a monomeric protein of 535 amino acids that, when glycosylated at two glycosylation sites, has a molecular weight of $70 \mathrm{kDa}$ (Fig. 2) [28]. Lysis at a protease cleavage motif at amino acid residue 427 explains the origin of the major MIS/AMH fragments (55 $\mathrm{kDa}$ amino-terminus and $12.5 \mathrm{kDa}$ carboxy-terminus) appearing on reduced polyacrylamide gels of the purified protein. A weaker motif at residue 229 is also present but its role in MIS/ $\mathrm{AMH}$ action is unclear. In the native molecule it is the carboxy-

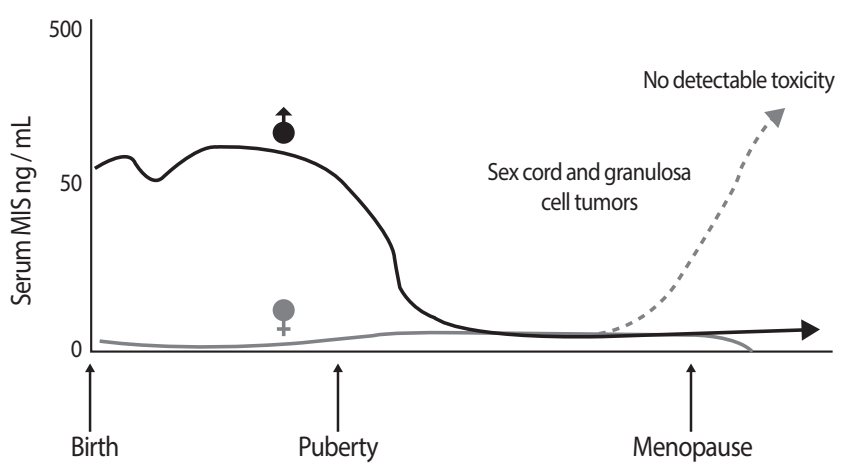

Fig. 1. MIS Expression is sexually dimorphic helpful in assessing of Intersex and gonadal tumor patients. Serum Müllerian inhibiting substance (MIS)/antiMüllerian hormone (AMH) in humans varies with sex and age. MIS/AMH in males is high at birth and levels are maintained until puberty. MIS/AMH in females becomes measurable at puberty and is gone by the menopause. Elevated MIS in females (dashed line) is consistent with granulosa/sex cord tumors. MIS levels drop in response to therapy (Reproduced from MacLaughlin DT, et al. Future Oncol 2010;6:391-405, with permission of Future Medicine Ltd.) [28]. 


\section{Obstetrics \& Gynecology Science}

Jang Heub Kim, et al. MIS/AMH: A novel treatment for Müllerian tumors

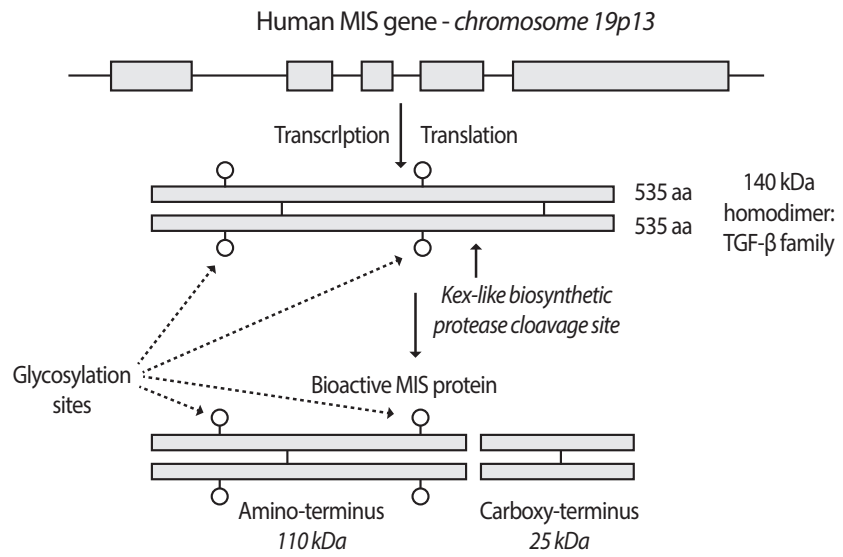

Fig. 2. The human Müllerian inhibiting substance (MIS)/anti-Müllerian hormone (AMH) gene has 5 exons and 4 introns and encodes a $70 \mathrm{kDa}$ monomer with two $\mathrm{N}$-linked glycosylation sites (circles). The disulfide-linked homodimer is activated by biosynthetic proteases to produce the $25-\mathrm{kDa}$ carboxy-terminal dimer. This domain is responsible for its bioactivity. The $110-k D a$ amino-terminus stays associated with the carboxy-terminus via non-covalent forces (Reproduced from MacLaughlin DT, et al. Future Oncol 2010;6:391-405, with permission of Future Medicine Ltd.) [28].

terminal disulfide linked homodimer $(25 \mathrm{kDa})$, which possesses the biological activity [58-60]. The amino-terminal domain may contribute to proper protein folding and assembly during synthesis and/or it may increase the serum half-life of the carboxy-terminus and enhance bioactivity [59]. The carboxyterminal sequence of MIS/AMH is extremely highly conserved, a fact that explains why MIS/AMH from many different species are all active in the rat in vitro bioassay used for MIS/AMH purification. The human gene was transfected into Chinese hamster ovary $(\mathrm{CHO})$ cells and its conditioned medium is used as a source of recombinant human MIS/AMH $[61,62]$ for purification of the MIS/AMH needed for all of our studies. The MIS/AMH as purified from serum free conditioned media is proteolytically processed by endogenous $\mathrm{CHO}$ enzymes, it is free of contaminants from bovine serum, hamster cells, and the mouse monoclonal antibody used to purify it [62], and significant amounts of endotoxins [45].

\section{Müllerian inhibiting substance/anti- Müllerian hormone receptors}

MIS/AMH biological activity requires interaction with two similar but distinct receptors termed type I and II. These single membrane spanning, serine-threonine kinases cross phosphorylate upon MIS/AMH binding and initiate intracellular cas-
Human MIS type II receptor gene - chromosome 12q13

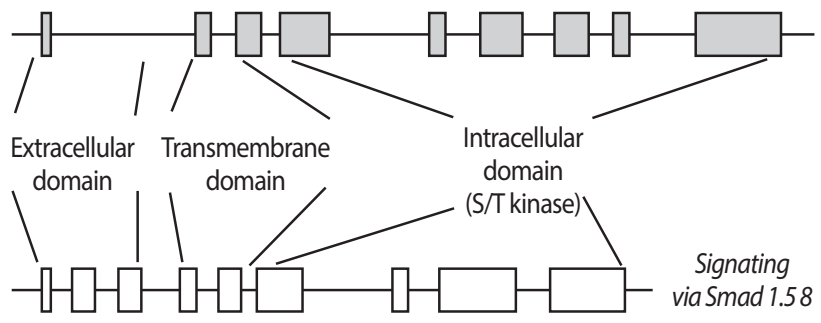

Human MIS type I receptor gene(s) Alk2, Alk3, Alk6

Fig. 3. MIS signals via a heteromeric receptor system. The human Müllerian inhibiting substance (MIS)/anti-Müllerian hormone (AMH) type II receptor gene has 11 exons and the type I gene has 9. They share several features including extracellular ligand-binding domains, transmembrane spanning regions and intracellular serine-threonine kinase domains. Both types are required for MIS/ $\mathrm{AMH}$ signaling and mutations in the type II receptor are associated with phenotypic changes in humans (Reproduced from MacLaughlin DT, et al. Future Oncol 2010;6:391-405, with permission of Future Medicine Ltd.) [28].

cades that lead to the control of cell cycle regulating proteins and altered transcription of a number of genes, depending upon the target tissues. The type II receptor binds the ligand and the type I heteromer is the signaling receptor (Fig. 3) [28]. The MIS/AMH type II receptor was cloned in the laboratories of Baarends and Themmen, Josso and Cate, and Behringer, as well as our own laboratory [63-66]. The human gene is located on chromosome $12 q 13$ [67] and has 11 exons and 10 introns.

The MIS/AMH type II receptor is expressed in Müllerian duct mesenchyme around the adjacent ductal epithelium, consistent with the fact that the fetal mesenchyme directs Müllerian duct regression [63-65]. The receptor is also found in fetal and adult Leydig and granulosa cells $[38,39,68,69]$ where it regulates testosterone $[24,38,39,68]$, estradiol and progesterone synthesis [69]. The MIS/AMH type II receptor is made by rodent uteri $[66,70]$, human endometrium [70], breast and prostate tissues $[42,44]$ and, surprisingly, in motor neurons in the mouse brain [41]. It is not yet understood what MIS/AMH is doing to these tissues but MIS/AMH inhibits the proliferation of tumor cell lines derived from them supporting our hypothesis that MIS/AMH may be a useful adjuvant agent in the treatment of these diseases.

Persistent Müllerian duct syndrome results from loss of function mutations in the MIS/AMH type II receptor and/or the MIS/AMH molecule itself [71]. A common mutation in the MIS/AMH gene deletes the carboxy-terminal domain and is therefore, it fails to regress the Müllerian duct. Heterozygotes 


\title{
Obstetrics \& Gynecology Science
}

\author{
Vol. 57, No. 5, 2014
}

of either mutation type, i.e. receptor or ligand have normal phenotypes; affected individuals are either homozygous for a given mutation or compound heterozygotes. Recently, a new intron mutation associated with Persistent Müllerian duct syndrome has been identified, as well [72].

Several different type I receptors (Alk2, Alk3, and Alk6) have been identified as interacting with the type II receptor [73-78]. How each type I receptor interacts with the type II receptor in human tissues is not know although all are expressed in the human cancer cell lines studied.

\section{Serum Müllerian inhibiting substance/ anti-Müllerian hormone clinical utility}

The discovery that males and females both express MIS/AMH postnatally prompted numerous studies which revealed the usefulness of measuring MIS/AMH in serum in a variety of clinical situations including ambiguous genitalia, undescended testes, delayed puberty, sex cord and granulosa cell tumors. Fortunately, three very useful human MIS/AMH-specific and highly sensitive immunoassays were developed concurrently by the Donahoe, Josso and Hutson laboratories [29-31] for this purpose and several are commercially available thus, impacting the practice of pediatric endocrinology, pediatric surgery and gynecologic oncology [29-31].

Serum MIS/AMH, is a strong predictor of the presence of testicular tissue when testes are not palpable [79]. It also is a useful indicator of testis function in these cases and in cases of sexual ambiguity. Normal MIS/AMH levels are consistent with normal testes, undetectable MIS/AMH reflects absent testes whereas, low MIS/AMH is often due to gonadal dysgenesis. Serum MIS/AMH data can be more useful than hCG stimulation tests to evaluate gonadal status.

Serum MIS/AMH correlates with ovarian reserve and it is an indicator of response to in vitro fertilization protocols $[36,80$ 85]. The vast majority of sex cord and granulosa cell tumors $[86,87]$ secrete MIS/AMH in proportion to tumor burden [88] and changes in serum MIS/AMH reflect recurrences and/or response to therapy. These tumors may express the MIS/AMH receptor [89] but the tumors are not responsive to the MIS/ AMH they produce. This fact implies a loss of function downstream from the receptor itself, therefore, these tumors are not considered targets for MIS/AMH therapy. Serum concentrations of MIS/AMH above the normal for age is consistent with the presence of either one of these tumors; rising serum
MIS/AMH reflects tumor growth and decreases show response to therapy [86]. MIS/AMH levels can reach thousands fold the normal range without any adverse reactions that could be attributed to the MIS/AMH molecule. It is for this reason that we predict that MIS/AMH administered to cancer patients as a may have a very favorable toxicity profile (see below). Whether recombinant human MIS/AMH is toxic will be the topic of detailed toxicology studies planned for the future when clinical grade MIS/AMH is available.

\section{Müllerian inhibiting substance/anti- Müllerian hormone and cancer therapy}

Much of the research effort has focused the molecular mechanism of action of MIS/AMH [90-93]. A major goal of this work is to translate findings into new therapies or diagnostic tools for the management of pediatric diseases requiring medical intervention and/or surgical reconstruction. In addition to the clinical uses of MIS/AMH measurements listed above, an unexpected consequence of the knowledge gained form basic MIS/ $\mathrm{AMH}$ research is the use of recombinant human MIS/AMH as a novel, naturally occurring, potentially nontoxic, cancer drug administered to patients with MIS/AMH receptor expressing malignancies.

As it became clear that MIS/AMH inhibits cell division and/ or induces apoptosis in a highly specific manner, it was suggested by a colleague of ours, Professor Robert Scully of the Massachusetts General Hospital Pathology Department and an expert in ovarian cancer, that MIS/AMH might be an inhibitor of cancers of Müllerian duct origin. His observation that epithelial ovarian cancers recapitulate embryonic Müllerian histology [94], lead to the logical question of whether these lesions could be MIS/AMH targets. If so, administration of exogenous MIS/AMH could be an effective, highly specific reagent to include in existing treatments for epithelial ovarian cancer [9599]. Results of more recent experiments, however, identify cervical and endometrial cancers as other potential targets $[70,100]$, as well as several non-Müllerian cancers, including breast $[43,45,46]$, prostate [43] and ocular melanoma [47] (see below). Our original hypothesis, therefore, is extended to include any tumor that expresses a functional MIS/AMH type II receptor. After examining a considerable body of pre-clinical experimental results we conclude that MIS/AMH may indeed be a useful cancer drug and we propose that phase I trials be initiated as soon as sufficient clinical grade material is avail- 


\section{Obstetrics \& Gynecology Science}

Jang Heub Kim, et al. MIS/AMH: A novel treatment for Müllerian tumors

able.

The concept that a naturally occurring growth inhibitor such as MIS/AMH could be an effective adjuvant treatment for cancer is attractive because MIS/AMH type II receptor expression is restricted to so few tissues thus minimizing the potential for adverse side effects. For the same reason, MIS/AMH may be used as a delivery system for more toxic drugs, again limiting exposure to non-target tissues. Our choice to focus initially on certain of the ovarian cancers arises from the fact that they have, when compared with other potential MIS/AMH targets, the worst prognosis and might benefit significantly from this novel biological reagent, thus offering a new approach to augment the efforts of others to find useful new strategies to employ.

\section{Müllerian inhibiting substance/anti-Müllerian hormone and ovarian cancer}

Validating MIS/AMH as an anti-cancer drug particularly for ovarian cancers has been the focus of our laboratory since we first hypothesized that any cancer of Müllerian origin could be a target for MIS/AMH treatment $[95,96]$. The notion that MIS/ $\mathrm{AMH}$ could be used to treat ovarian cancer is predicted by the fact that the histology of the embryonic Müllerian ducts is somewhat reproduced in the common ovarian adenocarcinomas that can arise from the outer ovarian coelomic epithelium.

Epithelial ovarian cancer affects nearly 25,000 North American women each year and is the fifth most common malignancy in women with a five-year mortality of over $70 \%$ [101]. The mortality rate is significantly lower in stage la or lb disease, but early peritoneal seeding and metastatic spread accounts for the fact that less than $25 \%$ of women are diagnosed with early stage disease. Combined surgery and cytotoxic therapy produce favorable clinical responses in $50 \%$ to $80 \%$ of patients but, unfortunately, the majority of patients relapse, therefore, it is timely to search for novel therapies for ovarian cancer $[99,102]$.

Our hypothesis was supported by results of initial in vitro studies using human ovarian cancer cell lines $[96,103-105]$ or tissues [106] followed by a series of ex-vivo experiments with human cancer cell lines [98]. Studies were also conducted on ovarian cancer cells in ascites specimens harvested collected from patients with new or recurrent disease [97]. Importantly, over $50 \%$ of the stage III ovarian patients had cells that bound recombinant human MIS/AMH, expressed the MIS/AMH type II receptor, and were growth inhibited by MIS/AMH [97]. Two other more recent studies corroborate and extend these findings on the incidence of receptor expression in benign and malignant cancers of Müllerian origin $[107,108]$. Therefore, the incidence of MIS/AMH responsive cases is sufficiently high to warrant further clinical investigation. The observations on fresh surgical specimens and ascitic fluid, however, are perhaps the most significant to date as they reflect what is true for patients and not cell lines. Receptor expression is frequent in a random sample of ovarian cancer cases and the receptor appears to be functional as MIS/AMH inhibits cancer cell proliferation in vitro [97].

The pre-clinical studies of MIS/AMH in ovarian cancer were advanced greatly by the development of a new mouse model by Dr. Connolly and colleagues at the Fox Chase Cancer Center [109]. These tumors appear very similar to the phenotype of the most common human ovarian cancer, serous cystadenocarcinoma with a relatively large percentage (50\%) of mice developing cancers within a few months of birth. Cell lines from these tumors, called MOVCAR cells, express the MIS/AMH type II receptor mRNA, they grew rapidly in culture, and they respond to MIS/AMH in vitro in a dose dependent manner with up to 95\% growth inhibition (Fig. 4) [110]. To study the effects of MIS/AMH in vivo, nude mice were injected in the leg or into the dorsal fat pad with MOVCAR tumor cells at six weeks of age. Tumors appeared in a dose dependent manner in both implantation sites. When 10,000 cells were injected tumors appeared in approximately ten weeks. By comparison, 100,000 cells produced tumors in eight weeks, and tumors were visible in nine weeks after injection of $3 \times 106$ cells, and 12×106 cells produced tumors in approximately four weeks. Intraperitoneal injection of the animals with MIS/AMH lengthened the time to tumor appearance and tumor volume significantly smaller (Fig. 5). No apparent toxicity was detected and considering the fact that this duration of MIS/AMH exposure in the mouse is roughly equivalent to about 7 years of continuous cancer treatment in human, MIS/AMH may be relatively safe. In a preliminary experiment, a MOVCAR tumor was allowed to grow for over 20 weeks in the fat-pad before MIS/AMH treatment. The tumor completed regressed after 5 weeks of treatment days of treatment (Fig. 6) [111]. The buffer control treated animal's tumor continued to grow.

After phase I trials are completed MIS/AMH will most likely be administered to patients in simultaneously with other drugs. It was important, therefore, to study potential interactions between MIS/AMH and commonly used cytotoxic agents. Mechanism of action studies thus far show that MIS/ 


\title{
Obstetrics \& Gynecology Science
}

\author{
Vol. 57, No. 5, 2014
}

AMH downstream signal transduction pathways include Smads, cyclin dependent kinase inhibitors, and cytokine inducible pathways. MIS/AMH also increased expression of p16, an inhibitor of cell cycle progression, the pocket proteins p107, and p130 as well as the apoptosis associated-E2F1 protein [105]. Another study reported last year has identified a number of other genes that are up and down regulated by MIS/ AMH in an ovarian cancer cell line [112]. These results suggest MIS/AMH mechanisms of action very different from those of targeted by most chemotherapeutic agents. If MIS/AMH and drugs can function in combination it may be possible to decrease the dose needed for either agent alone, potentially resulting in decreased toxicity. In fact, preliminary studies with epithelial ovarian cancers in vitro demonstrated that combination therapy with MIS/AMH may indeed provide a means of reducing toxicity while maintaining or enhancing clinical effec-
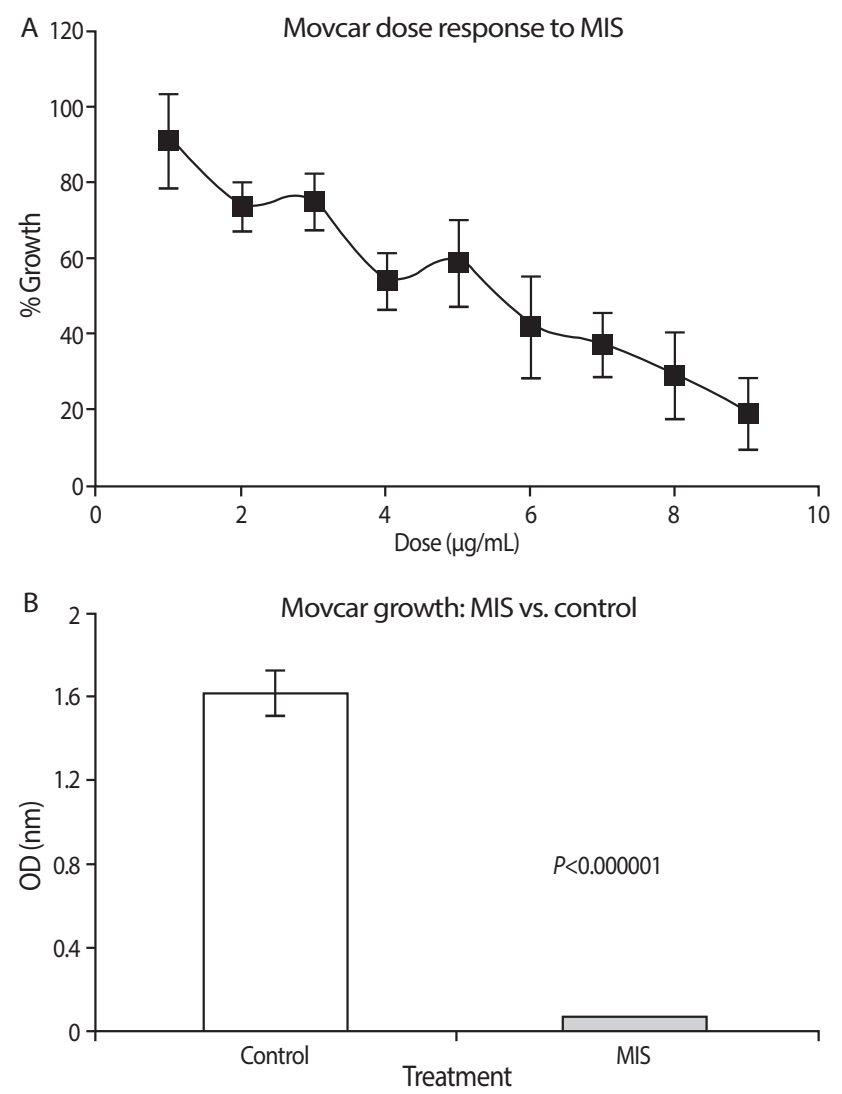

Fig. 4. Recombinant human Müllerian inhibiting substance (MIS)/antiMüllerian hormone (AMH) inhibits MOVCAR cell lines in vitro in a dose dependent manner (A). (B) shows the mean level of inhibition of MOVCAR cells by $71 \mathrm{nM}$ MIS/AMH in six different experiments; approximately $95 \%$ compared to controls in a colorimetric cell count assay (From PierettiVanmarcke R, et al. Clin Cancer Res 2006;12:1593-8, with permission from American Association for Cancer Research) [110]. tiveness (Fig. 7) [113]. Using MOVCAR cells from the murine model dose responses to rapamycin, and three ovarian cancer chemotherapeutic drugs paclitaxel, cisplatin, and doxorubicin were established and the effect of added recombinant human MIS/AMH determined. These studied showed that rapamycin and MIS/AMH were synergistic; MIS/AMH and paclitaxel were additive; MIS/AMH and cisplatin were additive; and the combination of doxorubicin and MIS/AMH was synergistic.

The ultimate translation of MIS/AMH as a therapeutic, from studies on cancers in vitro, to preclinical trials in animals, and eventually to phase I clinical trials, means sufficient quantities of clinical grade recombinant human MIS/AMH need to be produced. Accordingly, our laboratory has spent considerable effort optimizing purification protocols from mammalian cells and is exploring a number of alternative sources for enhanced production of MIS/AMH. In addition, we have developed MIS/
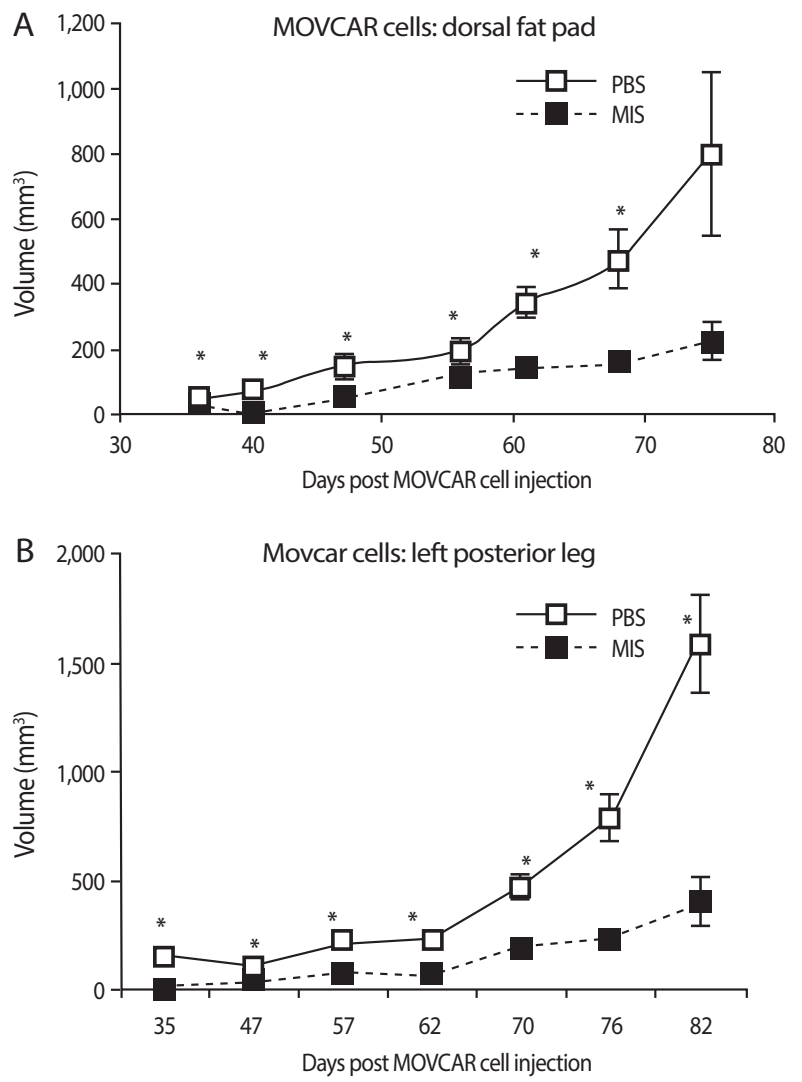

Fig. 5. Recombinant human Müllerian inhibiting substance (MIS)/antiMüllerian hormone (AMH) decreases growth of MOVCAR allografts in nude mice. Cells were injected in the dorsal fat pad (A) or the left leg $(B)$ and animals treated with PBS or MIS/AMH. Tumor volumes (+/- SEM) 35 to 82 days after injection are shown (From Pieretti-Vanmarcke $\mathrm{R}$, et al. Clin Cancer Res 2006;12:1593-8, with permission from American Association for Cancer Research) [110]. * Significant from control. 


\section{Obstetrics \& Gynecology Science}

Jang Heub Kim, et al. MIS/AMH: A novel treatment for Müllerian tumors

AMH-specific assays to detect the protein and measure its bioactivity with a high degree of precision.

\section{Müllerian inhibiting substance/anti-Müllerian hormone and other Müllerian tissues and cancers}

Normal cervix and cervical tumors express the MIS/AMH type
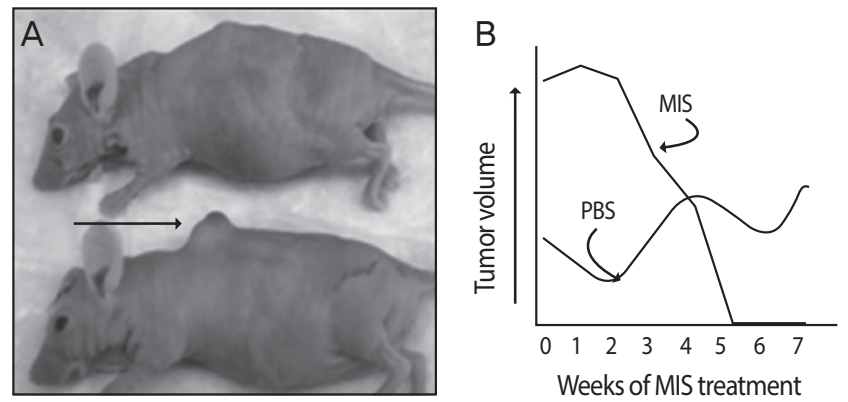

Fig. 6. Müllerian inhibiting substance (MIS)/anti-Müllerian hormone given intraperitoneally for 38 days to a mouse after a dorsal fat pad tumor had formed ablated the mass. (A) shows the treated animal (top) and the control animal (bottom) with its tumor (arrow). Tumor volume measurements are given in (B) (From Jakowlew SB, editor. Transforming growth factor[beta] in cancer therapy. 1st ed. Totowa: Humana Press; 2008, with permission from Springer ) [111].
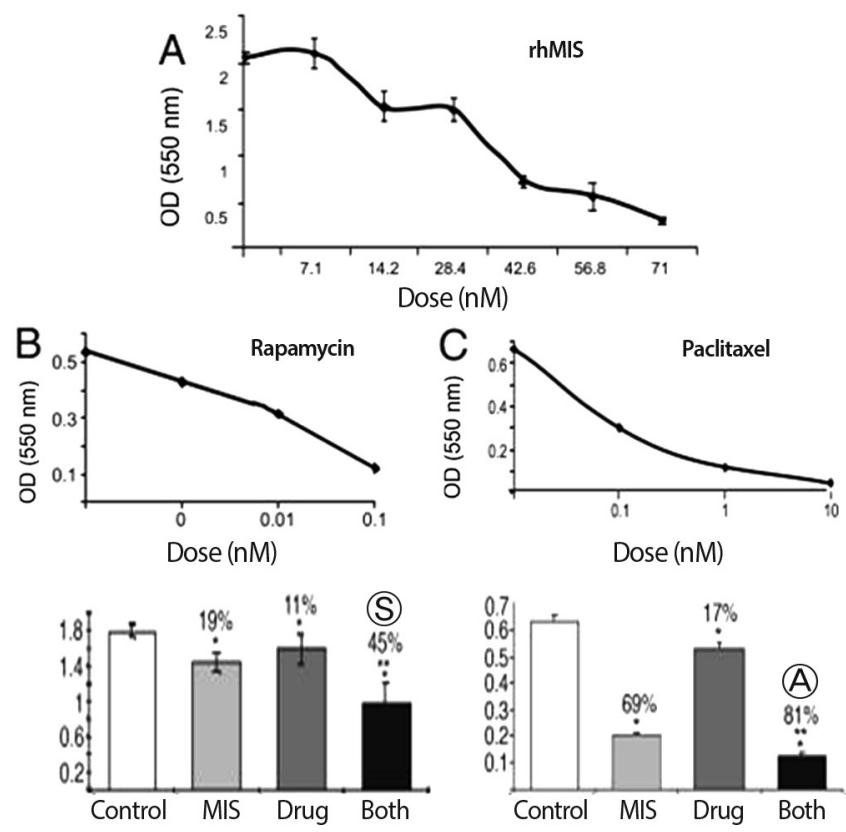

II receptor protein by immunohistochemistry and mRNA by RTPCR (Fig. 8) [100]. Human cervical cancer cell lines respond to MIS/AMH. Three human cervical carcinoma cell lines, CaSki, $\mathrm{SiHa}$, and C33A were all growth inhibited in vitro by MIS/AMH added to the growth media or MIS/AMH produced by the cells themselves after transient transfection with a transcript encoding bioactive MIS/AMH (Fig. 9) [114]. As is true of ovarian cancer cell lines MIS/AMH upregulated p16, p130, p107, E2F1 in the C33A cell line. Interestingly, overexpression of p16, p130, p107, or E2F1 inhibited cell growth compared to vectors alone [100]. These findings in cervical cancer further broaden the targets for MIS/AMH.

In addition to the cervix, Fallopian tubes, and the ovarian lining, the uterus is also a Müllerian structure. The MIS/AMH type II receptor mRNA is expressed in the Müllerian ducts of the female rat embryo between days 13 and 19 of development and in the uterine mesenchyme during the first postnatal days. The MIS/AMH type II receptor protein was also detected in a human endometrial cancer cell line AN3CA [70] and normal and pregnant adult rat uterus by western analysis [70] but not in small intestine (Fig. 10) [70]. In the human, MIS/AMH type II receptor mRNA was detected in myometrium and endometrium of a
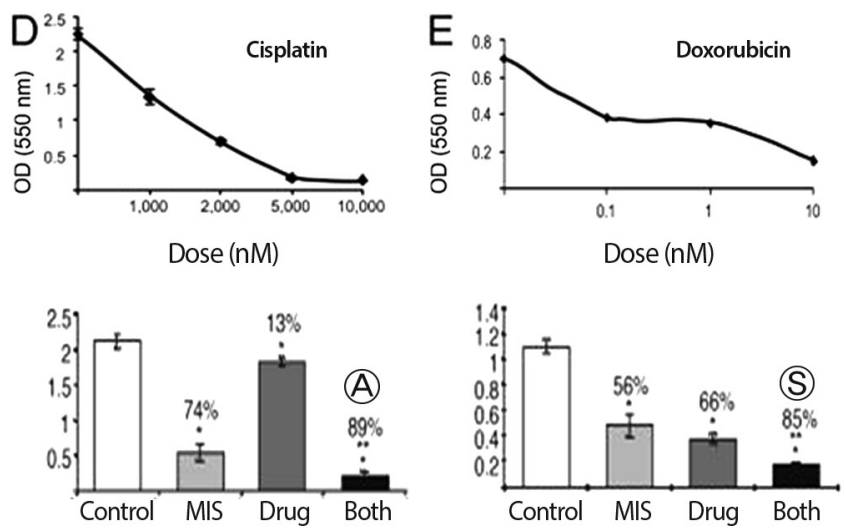

Fig. 7. In vitro dose responses for MOVCAR7 cells for Müllerian inhibiting substance (MIS)/anti-Müllerian hormone (AMH) and rapamycin, paclitaxel, cisplatin and doxorubicin alone (A-E) and results of combination treatments (bar graphs, bottom) are shown. Rapamycin and doxorubicin were synergistic with MIS/AMH (S); Paclitaxel and cisplatin were additive (A). Significant inhibition relative to controls is indicated by an asterisk ( ${ }^{*}$ ); MIS/AMH alone was always significantly different from combination treatment ${ }^{* *}$ ) (From Pieretti-Vanmarcke R, et al. Proc Natl Acad Sci U S A 2006;103:17426-31, with permission from National Academy of Sciences) [113]. 


\title{
Obstetrics \& Gynecology Science
}

\author{
Vol. 57, No. 5, 2014
}

post-menopausal uterus and the protein observed by western analysis in endometrial tumors. Two cancer cell lines which express the receptor mRNA and protein were inhibited by MIS/

A C33A
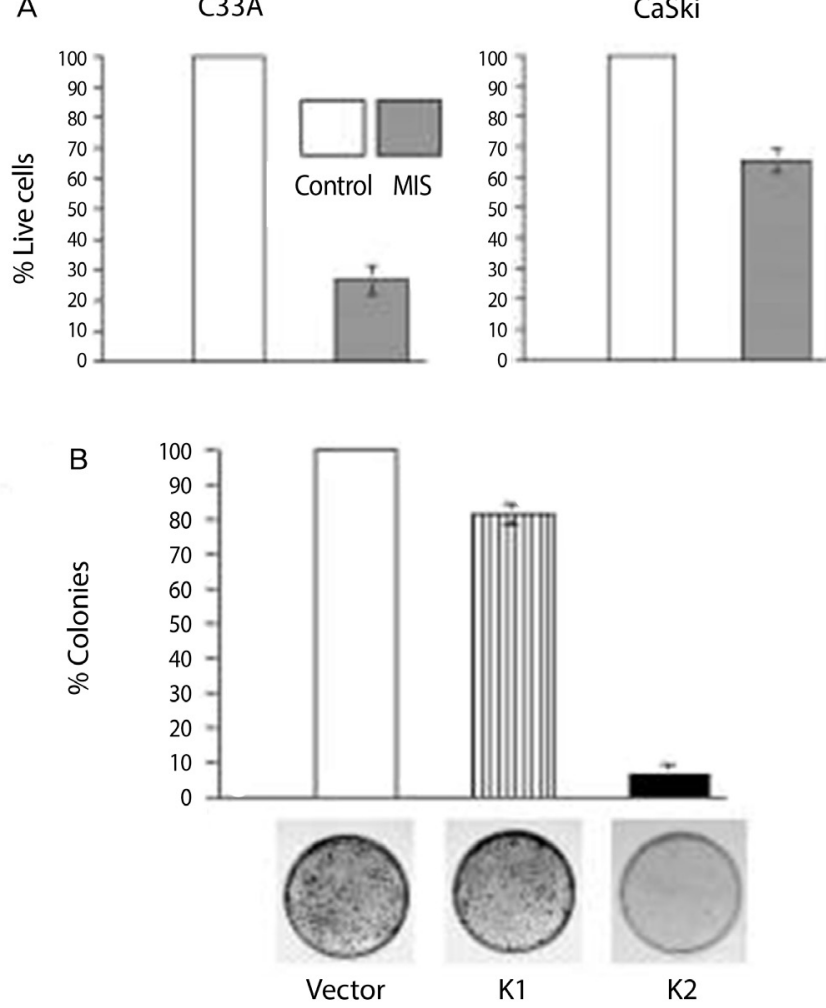

Fig. 8. (A) Inhibition of cervical cancer cell growth by Müllerian inhibiting substance (MIS)/anti-Müllerian hormone (AMH) for C33A and CaSki cells, after 4 days of MIS/AMH treatment $(P<0.001)$. (B) C33A cells stably transfected with empty vector, an inactive MIS/AMH (K1), or bioactive MIS/AMH (K2). K1 had little effect, whereas active MIS/AMH inhibited to over 90\% (From Barbie TU, et al. Proc Natl Acad Sci U S A 2003;100:15601-6, with permission from National Academy of Sciences) [100].

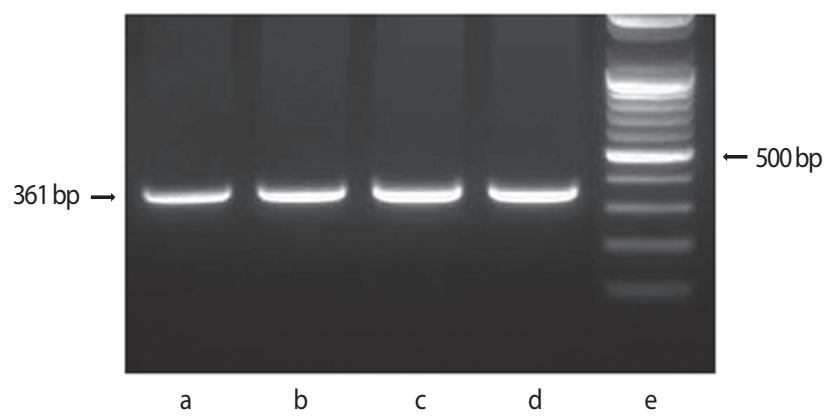

Fig. 9. RT-PCR of Müllerian inhibiting substance type II receptor mRNA from human cervix and cervical cancers. Bands of 361 bp are detected in normal cervix (a,b), squamous cell carcinoma of cervix (c), and adenocarcinoma of cervix (d). Lane (e) is the DNA ladder [114].
AMH as well (Fig. 11) [70]. AN3CA, an endometrial carcinoma metastasis, showed significant growth inhibition (57\% to $67 \%$ inhibition relative to control, $0 \%$ ). KLE, a human cell line derived from a poorly differentiated endometrial cancer, also demonstrated significant growth inhibition (44.9\%) after treatment with MIS/AMH. The cervical and endometrial transfection data support the conclusion that the growth inhibition effects are due to the MIS/AMH molecule itself rather than a contaminant in the purified protein preparation. Unlike the ovarian and cervical cancer cell lines AN3CA cells do not express p16 or p21 but MIS/AMH does induce p107, p130 and E2F1 [70].

\section{Müllerian inhibiting substance/anti-Müllerian hormone and non-Müllerian tissues and cancers}

It is noteworthy that MIS/AMH type II receptor is expressed in locations other than Müllerian tissues and gonads. In ad-

A
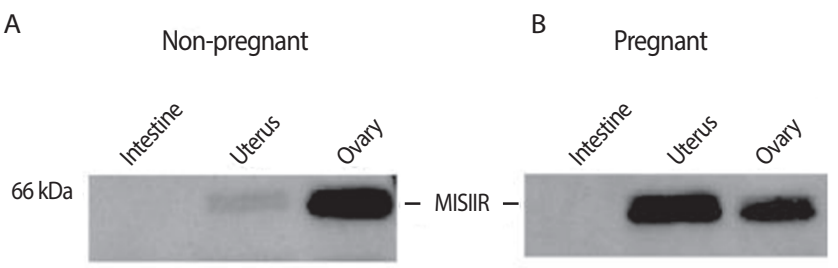

Fig. 10. Müllerian inhibiting substance/anti-Müllerian hormone type II receptor protein expression in the rat uterus. Pregnant $(A)$ and non-pregnant (B) uteri and ovary are positive for the receptor but not intestine by western assay. Receptor expression may increase with pregnancy (From Renaud EJ, et al. Proc Natl Acad Sci U S A 2005;102:111-6, with permission from National Academy of Sciences) [70].

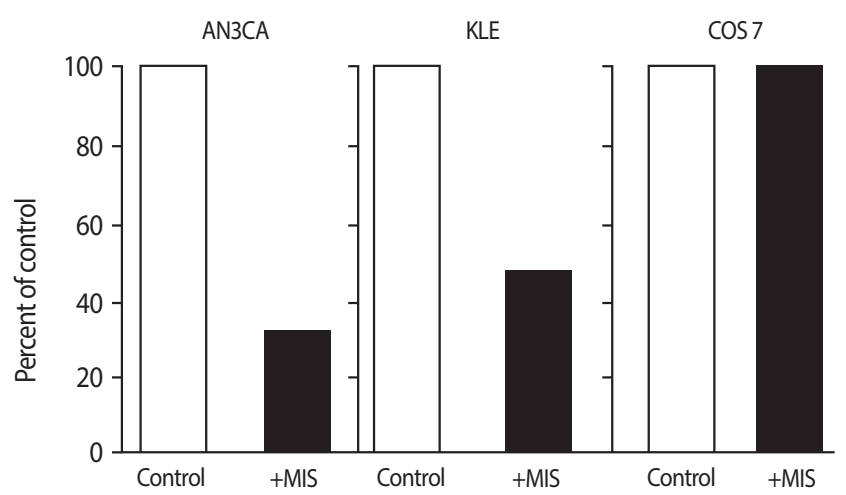

Fig. 11. $71 \mathrm{nM}$ recombinant human Müllerian inhibiting substance (MIS)/ anti-Müllerian hormone (AMH) significantly inhibits proliferation of human endometrial cancer cell lines AN3CA (by 67\%) and KLE (by 52\%) compared with cells treated with buffer control. MIS/AMH did not inhibit the growth of COS 7 cells, which do not express the MIS/AMH type II receptor (From Renaud EJ, et al. Proc Natl Acad Sci U S A 2005;102:111-6, with permission from National Academy of Sciences) [70]. 


\section{Obstetrics \& Gynecology Science}

Jang Heub Kim, et al. MIS/AMH: A novel treatment for Müllerian tumors

dition to the ocular melanoma already mentioned, MIS/AMH type II receptor is expressed in motor neurons [41] and the normal rat breast epithelium at levels inversely proportional to the state of proliferation of the tissue [44]. In several estrogen receptor positive and negative human breast cancer cell lines MIS/AMH enhanced IKB dependent DNA binding of NFKB that resulted in induction of IEX-1 mRNA [44], an immediate early gene induced by radiation, interferon $\gamma$, or tumor necrosis factor alpha but not by TGF $\beta[45,116,117]$. Apoptosis was enhanced in the mammary epithelium of MIS/AMH injected animals compared to control animals [44], therefore, breast cancer could well be another target for MIS/AMH therapy.

MIS/AMH treatment of cancer may also include the prostate $[42,43]$. The MIS/AMH type II receptor and two candidate MIS/ AMH type I receptors [74-78] are expressed in a prostatic cancer cell line (LNCaP) as well as in human prostate tumors [42]. MIS/AMH blocks the growth of human prostate cancer cell lines and it induces IRF1, and interferon $\gamma$ was that enhances the inhibiting effects of MIS/AMH in vitro and in vivo. Furthermore, because MIS/AMH suppresses testosterone production [13,37-39] it might indeed exert a double effect on prostatic cancer, a direct growth inhibition and an indirect effect by lowering testosterone.

\section{Müllerian inhibiting substance/anti- Müllerian hormone and endometriosis}

Endometriosis is a common benign disease of reproductive women, especially infertile women. Ectopic endometrial cells exhibit abnormal proliferative and apoptotic regulation in endometriosis. Recent reports show that MIS induces the cell cycle arrest and apoptosis of human endometrial stromal cells and endometriosis cell line in vitro. One study shows that the celluar apoptosis was increased by causing arrest at $G_{1}$ phase and increasing cells at sub-GoG 1 phase in endometrial stromal cells treated with MIS for 72 hours (Fig. 12) [118]. Another study shows that MIS induces autophagy through increased expression of Beclin-1 autophagy-promoting protein in endometriosis cell line [119]. These findings suggest that MIS play an important role in cellular apoptosis in endometriosis. Therefore, MIS has a potential as a therapeutic modalities in endometriosis.

\section{Conclusion}

The existing literature on MIS/AMH suggests that the recom-

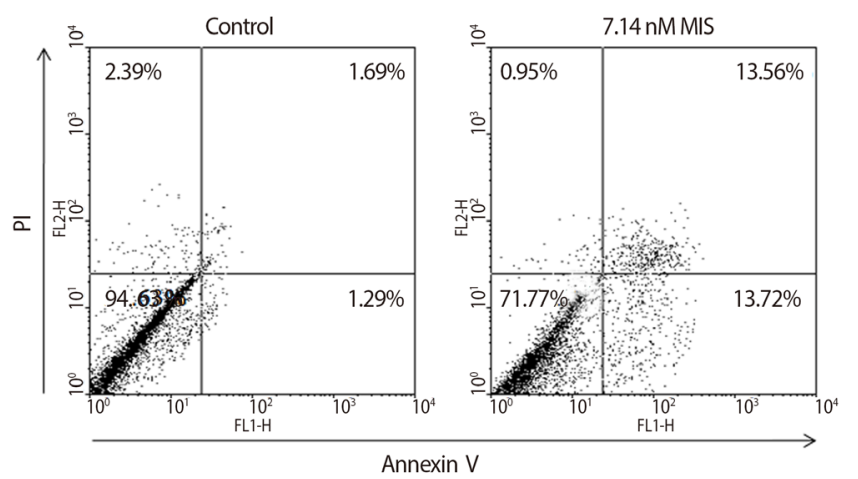

\begin{tabular}{cc} 
Sample & \% Apoptotic \\
\hline Control & 1.29 \\
7.14 nMMIS & 13.72
\end{tabular}

Fig. 12. Induction of early and late apoptosis by Müllerian inhibiting substance (MIS) in endometrial stromal cells. Cells were treated with $71 \mathrm{nM}$ MIS for 72 hours. For apoptosis, the externalization of phosphatidylserine was assessed by measuring annexin-V-FITC binding using propidium iodide as a counterstain. Quadrant rectangular dot grams from a representative of 3 independent experiments are shown (From Namkung J, et al. J Clin Endocrinol Metab 2012;97:3224-30, with permission from The Endocrine Society) [118].

binant human protein will have very little toxicity in vivo and that it should be tested against tumors expressing the MIS/ $\mathrm{AMH}$ type II receptor, perhaps beginning with ovarian cancer as among receptor expressing tumors, since it has the most dire prognosis. The molecular tools to identify MIS/AMH receptor expressing ovarian and gynecologic tumors are already in hand, thus, it is possible to select patients for treatment. An MIS/AMH ELISA exists to follow administered doses of MIS/ $\mathrm{AMH}$, as well. Clinical trials await the production of sufficient supplies of recombinant human MIS/AMH for this purpose.

\section{Conflict of interest}

No potential conflict of interest relevant to this article was reported.

\section{Acknowledgments}

The bulk of the research was funded by the National Institutes of Health (CA 17393-30) with additional support from the American Cancer Society, The Ovarian Cancer Research Fund, and the generous philanthropic support of the Mc- 


\title{
Obstetrics \& Gynecology Science
}

\author{
Vol. 57, No. 5, 2014
}

Bride family and The Commons Development Group Inc. Moreover, a part of study was supported by a grant from Department of Obstetrics and Gynecology, The Catholic University of Korea.

\section{References}

1. Goodfellow PN, Lovell-Badge R. SRY and sex determination in mammals. Annu Rev Genet 1993;27:71-92.

2. Jost $A$. Recherches sur la differenciation sexuelle de I'embryon de lapin. Arch Anat Microsc Morphol Exp 1947;36:271-315.

3. Jost A. Problems of fetal endocrinology: the gonadal and hypophyseal hormones. Rec Prog Horm Res 1953;8:379418.

4. Price JM, Donahoe PK, Ito Y, Hendren WH 3rd. Programmed cell death in the Mullerian duct induced by Mullerian inhibiting substance. Am J Anat 1977;149:353-75.

5. Price JM, Donahoe PK, Ito Y. Involution of the female Mullerian duct of the fetal rat in the organ-culture assay for the detection of Mullerian Inhibiting Substance. Am J Anat 1979;156:265-84.

6. Hayashi A, Donahoe PK, Budzik GP, Trelstad RL. Periductal and matrix glycosaminoglycans in rat Mullerian duct development and regression. Dev Biol 1982;92:16-26.

7. Trelstad RL, Hayashi A, Hayashi K, Donahoe PK. The epithelial-mesenchymal interface of the male rate Mullerian duct: loss of basement membrane integrity and ductal regression. Dev Biol 1982;92:27-40.

8. Ikawa H, Trelstad RL, Hutson JM, Manganaro TF, Donahoe PK. Changing patterns of fibronectin, laminin, type IV collagen, and a basement membrane proteoglycan during rat Mullerian duct regression. Dev Biol 1984;102:260-3.

9. Dyche WJ. A comparative study of the differentiation and involution of the Mullerian duct and Wolffian duct in the male and female fetal mouse. J Morphol 1979;162:175-209.

10. Josso N. In vitro synthesis of mullerian-inhibiting hormone by seminiferous tubules isolated from the calf fetal testis. Endocrinology 1973;93:829-34.

11. Blanchard MG, Josso N. Source of the anti-Mullerian hormone synthesized by the fetal testis: Mullerian-inhibiting activity of fetal bovine Sertoli cells in tissue culture. Pedi- atr Res 1974;8:968-71

12. Picon R. Action of the fetal testis on the development in vitro of the Mullerian ducts in the rat. Arch Anat Microsc Morphol Exp 1969;58:1-19.

13. Josso N, Forest MG, Picard JY. Mullerian-inhibiting activity of calf fetal testes: relationship to testosterone and protein synthesis. Biol Reprod 1975;13:163-7.

14. Donahoe PK, Ito Y, Price JM, Hendren WH 3rd. Mullerian inhibiting substance activity in bovine fetal, newborn and prepubertal testes. Biol Reprod 1977;16:238-43.

15. Josso N. Permeability of membranes to the Mullerian-inhibiting substance synthesized by the human fetal testis in vitro: a clue to its biochemical nature. J Clin Endocrinol Metab 1972;34:265-70.

16. Donahoe PK, Ito Y, Morikawa Y, Hendren WH. Mullerian inhibiting substance in human testes after birth. J Pediatr Surg 1977;12:323-30.

17. Shen WH, Moore CC, Ikeda Y, Parker KL, Ingraham HA. Nuclear receptor steroidogenic factor 1 regulates the mullerian inhibiting substance gene: a link to the sex determination cascade. Cell 1994;77:651-61.

18. Giuili G, Shen WH, Ingraham HA. The nuclear receptor SF-1 mediates sexually dimorphic expression of Mullerian Inhibiting Substance, in vivo. Development 1997;124:1799-807.

19. Arango NA, Lovell-Badge R, Behringer RR. Targeted mutagenesis of the endogenous mouse Mis gene promoter: in vivo definition of genetic pathways of vertebrate sexual development. Cell 1999;99:409-19.

20. Hossain A, Saunders GF. Role of Wilms tumor 1 (WT1) in the transcriptional regulation of the Mullerian-inhibiting substance promoter. Biol Reprod 2003;69:1808-14.

21. Nachtigal MW, Hirokawa Y, Enyeart-VanHouten DL, Flanagan JN, Hammer GD, Ingraham HA. Wilms' tumor 1 and Dax-1 modulate the orphan nuclear receptor SF-1 in sex-specific gene expression. Cell 1998;93:445-54.

22. Tremblay JJ, Viger RS. Nuclear receptor Dax-1 represses the transcriptional cooperation between GATA-4 and SF-1 in Sertoli cells. Biol Reprod 2001;64:1191-9.

23. Lasala C, Carre-Eusebe D, Picard JY, Rey R. Subcellular and molecular mechanisms regulating anti-Mullerian hormone gene expression in mammalian and nonmammalian species. DNA Cell Biol 2004;23:572-85.

24. Teixeira J, Fynn-Thompson E, Payne AH, Donahoe PK. Mullerian-inhibiting substance regulates androgen 


\section{Obstetrics \& Gynecology Science}

Jang Heub Kim, et al. MIS/AMH: A novel treatment for Müllerian tumors

synthesis at the transcriptional level. Endocrinology 1999; 140:4732-8.

25. Laurich VM, Trbovich AM, O'Neill FH, Houk CP, Sluss PM, Payne $\mathrm{AH}$, et al. Mullerian inhibiting substance blocks the protein kinase A-induced expression of cytochrome p450 17alpha-hydroxylase/C(17-20) lyase mRNA in a mouse Leydig cell line independent of cAMP responsive element binding protein phosphorylation. Endocrinology 2002;143:3351-60.

26. Sriraman V, Niu E, Matias JR, Donahoe PK, MacLaughlin DT, Hardy MP, et al. Mullerian inhibiting substance inhibits testosterone synthesis in adult rats. J Androl 2001;22:750-8.

27. Bezard J, Vigier B, Tran D, Mauleon P, Josso N. Immunocytochemical study of anti-Mullerian hormone in sheep ovarian follicles during fetal and post-natal development. J Reprod Fertil 1987;80:509-16.

28. MacLaughlin DT, Donahoe PK. Mullerian inhibiting substance/anti-Mullerian hormone: a potential therapeutic agent for human ovarian and other cancers. Future Oncol 2010;6:391-405.

29. Hudson PL, Dougas I, Donahoe PK, Cate RL, Epstein J, Pepinsky RB, et al. An immunoassay to detect human mullerian inhibiting substance in males and females during normal development. J Clin Endocrinol Metab 1990;70:16-22.

30. Josso N, Legeai L, Forest MG, Chaussain JL, Brauner R. An enzyme linked immunoassay for anti-mullerian hormone: a new tool for the evaluation of testicular function in infants and children. J Clin Endocrinol Metab 1990;70:23-7.

31. Baker ML, Metcalfe SA, Hutson JM. Serum levels of mullerian inhibiting substance in boys from birth to 18 years, as determined by enzyme immunoassay. J Clin Endocrinol Metab 1990;70:11-5.

32. Ueno S, Manganaro TF, Donahoe PK. Human recombinant mullerian inhibiting substance inhibition of rat oocyte meiosis is reversed by epidermal growth factor in vitro. Endocrinology 1988;123:1652-9.

33. Kim JH, Seibel MM, MacLaughlin DT, Donahoe PK, Ransil BJ, Hametz PA, et al. The inhibitory effects of mullerian-inhibiting substance on epidermal growth factor induced proliferation and progesterone production of human granulosa-luteal cells. J Clin Endocrinol Metab 1992;75:911-7.
34. Durlinger AL, Kramer $P$, Karels $B$, de Jong FH, Uilenbroek JT, Grootegoed JA, et al. Control of primordial follicle recruitment by anti-Mullerian hormone in the mouse ovary. Endocrinology 1999;140:5789-96.

35. Seifer DB, MacLaughlin DT, Penzias AS, Behrman HR, Asmundson L, Donahoe PK, et al. Gonadotropin-releasing hormone agonist-induced differences in granulosa cell cycle kinetics are associated with alterations in follicular fluid mullerian-inhibiting substance and androgen content. J Clin Endocrinol Metab 1993;76:711-4.

36. Seifer DB, MacLaughlin DT, Christian BP, Feng B, Shelden RM. Early follicular serum mullerian-inhibiting substance levels are associated with ovarian response during assisted reproductive technology cycles. Fertil Steril 2002;77:468-71.

37. Trbovich AM, Sluss PM, Laurich VM, O'Neill FH, MacLaughlin DT, Donahoe PK, et al. Mullerian Inhibiting Substance lowers testosterone in luteinizing hormone-stimulated rodents. Proc Natl Acad Sci U S A 2001;98:3393-7.

38. Lee MM, Seah CC, Masiakos PT, Sottas CM, Preffer Fl, Donahoe PK, et al. Mullerian-inhibiting substance type II receptor expression and function in purified rat Leydig cells. Endocrinology 1999;140:2819-27.

39. Baarends WM, Hoogerbrugge JW, Post M, Visser JA, De Rooij DG, Parvinen $M$, et al. Anti-mullerian hormone and anti-mullerian hormone type II receptor messenger ribonucleic acid expression during postnatal testis development and in the adult testis of the rat. Endocrinology 1995; 136:5614-22.

40. Bedecarrats GY, O'Neill FH, Norwitz ER, Kaiser UB, Teixeira J. Regulation of gonadotropin gene expression by Mullerian inhibiting substance. Proc Natl Acad Sci U S A 2003;100:9348-53.

41. Wang PY, Koishi K, McGeachie AB, Kimber M, Maclaughlin DT, Donahoe PK, et al. Mullerian inhibiting substance acts as a motor neuron survival factor in vitro. Proc Natl Acad Sci U S A 2005;102:16421-5.

42. Segev DL, Hoshiya Y, Hoshiya M, Tran TT, Carey JL, Stephen $A E$, et al. Mullerian-inhibiting substance regulates NF-kappa B signaling in the prostate in vitro and in vivo. Proc Natl Acad Sci U S A 2002;99:239-44.

43. Hoshiya Y, Gupta V, Segev DL, Hoshiya M, Carey JL, Sasur LM, et al. Mullerian Inhibiting Substance induces NFkB signaling in breast and prostate cancer cells. Mol 


\title{
Obstetrics \& Gynecology Science
}

\author{
Vol. 57, No. 5, 2014
}

Cell Endocrinol 2003;211:43-9.

44. Segev DL, Hoshiya Y, Stephen AE, Hoshiya M, Tran TT, MacLaughlin DT, et al. Mullerian inhibiting substance regulates NFkappaB signaling and growth of mammary epithelial cells in vivo. J Biol Chem 2001;276:26799-806.

45. Hoshiya Y, Gupta V, Kawakubo H, Brachtel E, Carey JL, Sasur $L$, et al. Mullerian inhibiting substance promotes interferon gamma-induced gene expression and apoptosis in breast cancer cells. J Biol Chem 2003;278:51703-12.

46. Gupta V, Carey JL, Kawakubo H, Muzikansky A, Green $J E$, Donahoe PK, et al. Mullerian inhibiting substance suppresses tumor growth in the C3(1)T antigen transgenic mouse mammary carcinoma model. Proc Natl Acad Sci U S A 2005;102:3219-24.

47. Parry RL, Chin TW, Epstein J, Hudson PL, Powell DM, Donahoe PK. Recombinant human mullerian inhibiting substance inhibits human ocular melanoma cell lines in vitro and in vivo. Cancer Res 1992;52:1182-6.

48. Vigier B, Picard JY, Josso N. A monoclonal antibody against bovine anti-Mullerian hormone. Endocrinology 1982;110:131-7.

49. Shima H, Donahoe PK, Budzik GP, Kamagata S, Hudson P, Mudgett-Hunter M. Production of monoclonal antibodies for affinity purification of bovine mullerian inhibiting substance activity. Hybridoma 1984;3:201-14.

50. Picard JY, Josso N. Anti-Mullerian hormone: estimation of molecular weight by gel filtration. Biomedicine 1976;25:147-50.

51. Picard JY, Josso N. Purification of testicular anti-Mullerian hormone allowing direct visualization of the pure glycoprotein and determination of yield and purification factor. Mol Cell Endocrinol 1984;34:23-9.

52. Swann DA, Donahoe PK, Ito Y, Morikawa Y, Hendren WH. Extraction of Mullerian inhibiting substance from newborn calf testis. Dev Biol 1979;69:73-84.

53. Budzik GP, Swann DA, Hayashi A, Donahoe PK. Enhanced purification of Mullerian inhibiting substance by lectin affinity chromatography. Cell 1980;21:909-15.

54. Budzik GP, Powell SM, Kamagata S, Donahoe PK. Mullerian inhibiting substance fractionation by dye affinity chromatography. Cell 1983;34:307-14.

55. Cate RL, Mattaliano RJ, Hession C, Tizard R, Farber NM, Cheung $A$, et al. Isolation of the bovine and human genes for Mullerian inhibiting substance and expression of the human gene in animal cells. Cell 1986;45:685-98.
56. Picard JY, Benarous R, Guerrier D, Josso N, Kahn A. Cloning and expression of CDNA for anti-mullerian hormone. Proc Natl Acad Sci U S A 1986;83:5464-8.

57. Cohen-Haguenauer O, Picard JY, Mattei MG, Serero S, Nguyen VC, de Tand MF, et al. Mapping of the gene for anti-mullerian hormone to the short arm of human chromosome 19. Cytogenet Cell Genet 1987;44:2-6.

58. Pepinsky RB, Sinclair LK, Chow EP, Mattaliano RJ, Manganaro TF, Donahoe PK, et al. Proteolytic processing of mullerian inhibiting substance produces a transforming growth factor-beta-like fragment. J Biol Chem 1988;263:18961-4.

59. MacLaughlin DT, Hudson PL, Graciano AL, Kenneally MK, Ragin RC, Manganaro TF, et al. Mullerian duct regression and antiproliferative bioactivities of mullerian inhibiting substance reside in its carboxy-terminal domain. Endocrinology 1992;131:291-6.

60. Wilson CA, di Clemente N, Ehrenfels C, Pepinsky RB, Josso N, Vigier $B$, et al. Mullerian inhibiting substance requires its $\mathrm{N}$-terminal domain for maintenance of biological activity, a novel finding within the transforming growth factor-beta superfamily. Mol Endocrinol 1993;7:247-57.

61. Ragin RC, Donahoe PK, Kenneally MK, Ahmad MF, MacLaughlin DT. Human mullerian inhibiting substance: enhanced purification imparts biochemical stability and restores antiproliferative effects. Protein Expr Purif 1992;3:236-45.

62. Lorenzo HK, Teixeira J, Pahlavan N, Laurich VM, Donahoe PK, MacLaughlin DT. New approaches for high-yield purification of Mullerian inhibiting substance improve its bioactivity. J Chromatogr B Analyt Technol Biomed Life Sci 2002;766:89-98.

63. Baarends WM, van Helmond MJ, Post M, van der Schoot PJ, Hoogerbrugge JW, de Winter JP, et al. A novel member of the transmembrane serine/threonine kinase receptor family is specifically expressed in the gonads and in mesenchymal cells adjacent to the mullerian duct. Development 1994;120:189-97.

64. Di Clemente N, Wilson C, Faure E, Boussin L, Carmillo $P$, Tizard $R$, et al. Cloning, expression, and alternative splicing of the receptor for anti-Mullerian hormone. Mol Endocrinol 1994;8:1006-20.

65. Teixeira J, He WW, Shah PC, Morikawa N, Lee MM, Catlin $\mathrm{EA}$, et al. Developmental expression of a candidate 


\section{Obstetrics \& Gynecology Science}

Jang Heub Kim, et al. MIS/AMH: A novel treatment for Müllerian tumors

mullerian inhibiting substance type II receptor. Endocrinology 1996;137:160-5.

66. Mishina Y, Tizard R, Deng JM, Pathak BG, Copeland NG, Jenkins NA, et al. Sequence, genomic organization, and chromosomal location of the mouse Mullerian-inhibiting substance type II receptor gene. Biochem Biophys Res Commun 1997;237:741-6.

67. Imbeaud S, Faure E, Lamarre I, Mattei MG, di Clemente $\mathrm{N}$, Tizard $\mathrm{R}$, et al. Insensitivity to anti-mullerian hormone due to a mutation in the human anti-mullerian hormone receptor. Nat Genet 1995;11:382-8.

68. Racine C, Rey R, Forest MG, Louis F, Ferre A, Huhtaniemi I, et al. Receptors for anti-mullerian hormone on Leydig cells are responsible for its effects on steroidogenesis and cell differentiation. Proc Natl Acad Sci U S A 1998;95:594-9.

69. Baarends WM, Uilenbroek JT, Kramer P, Hoogerbrugge JW, van Leeuwen EC, Themmen AP, et al. Anti-mullerian hormone and anti-mullerian hormone type II receptor messenger ribonucleic acid expression in rat ovaries during postnatal development, the estrous cycle, and gonadotropin-induced follicle growth. Endocrinology 1995;136:4951-62.

70. Renaud EJ, MacLaughlin DT, Oliva E, Rueda BR, Donahoe PK. Endometrial cancer is a receptor-mediated target for Mullerian Inhibiting Substance. Proc Natl Acad Sci U S A 2005;102:111-6.

71. Josso N, Belville C, di Clemente N, Picard JY. AMH and $\mathrm{AMH}$ receptor defects in persistent Mullerian duct syndrome. Hum Reprod Update 2005;11:351-6.

72. Hoshiya M, Christian BP, Cromie WJ, Kim H, Zhan Y, MacLaughlin DT, et al. Persistent Mullerian duct syndrome caused by both a 27-bp deletion and a novel splice mutation in the MIS type II receptor gene. Birth Defects Res A Clin Mol Teratol 2003;67:868-74.

73. Gouedard L, Chen YG, Thevenet L, Racine C, Borie S, Lamarre I, et al. Engagement of bone morphogenetic protein type IB receptor and Smad1 signaling by antiMullerian hormone and its type II receptor. J Biol Chem 2000;275:27973-8.

74. Visser JA, Olaso R, Verhoef-Post $M$, Kramer $P$, Themmen $A P$, Ingraham HA. The serine/threonine transmembrane receptor ALK2 mediates Mullerian inhibiting substance signaling. Mol Endocrinol 2001;15:936-45.

75. Jamin SP, Arango NA, Mishina Y, Hanks MC, Behringer
RR. Requirement of Bmpr1a for Mullerian duct regression during male sexual development. Nat Genet 2002;32:408-10.

76. He WW, Gustafson ML, Hirobe S, Donahoe PK. Developmental expression of four novel serine/threonine kinase receptors homologous to the activin/transforming growth factor-beta type II receptor family. Dev Dyn 1993; 196:133-42.

77. Clarke TR, Hoshiya Y, Yi SE, Liu X, Lyons KM, Donahoe PK. Mullerian inhibiting substance signaling uses a bone morphogenetic protein (BMP)-like pathway mediated by ALK2 and induces SMAD6 expression. Mol Endocrinol 2001;15:946-59.

78. Gu Z, Reynolds EM, Song J, Lei H, Feijen A, Yu L, et al. The type I serine/threonine kinase receptor ActRIA (ALK2) is required for gastrulation of the mouse embryo. Development 1999;126:2551-61.

79. Lee MM, Donahoe PK, Silverman BL, Hasegawa T, Hasegawa Y, Gustafson ML, et al. Measurements of serum mullerian inhibiting substance in the evaluation of children with nonpalpable gonads. N Engl J Med 1997;336:1480-6.

80. Van Rooij IA, Broekmans FJ, te Velde ER, Fauser BC, Bancsi LF, de Jong $F H$, et al. Serum anti-Mullerian hormone levels: a novel measure of ovarian reserve. Hum Reprod 2002;17:3065-71.

81. Muttukrishna S, Suharjono H, McGarrigle H, Sathanandan $\mathrm{M}$. Inhibin $\mathrm{B}$ and anti-Mullerian hormone: markers of ovarian response in IVF/ICSI patients? BJOG 2004;111:1248-53.

82. Hazout A, Bouchard P, Seifer DB, Aussage P, Junca AM, Cohen-Bacrie $P$. Serum antimullerian hormone/mullerianinhibiting substance appears to be a more discriminatory marker of assisted reproductive technology outcome than follicle-stimulating hormone, inhibin B, or estradiol. Fertil Steril 2004;82:1323-9.

83. Penarrubia J, Fabregues F, Manau D, Creus M, Casals G, Casamitjana $\mathrm{R}$, et al. Basal and stimulation day 5 antiMullerian hormone serum concentrations as predictors of ovarian response and pregnancy in assisted reproductive technology cycles stimulated with gonadotropinreleasing hormone agonist: gonadotropin treatment. Hum Reprod 2005;20:915-22.

84. Eldar-Geva T, Ben-Chetrit A, Spitz IM, Rabinowitz R, Markowitz $E$, Mimoni T, et al. Dynamic assays of inhibin 


\section{Obstetrics \& Gynecology Science}

Vol. 57, No. 5, 2014

$\mathrm{B}$, anti-Mullerian hormone and estradiol following FSH stimulation and ovarian ultrasonography as predictors of IVF outcome. Hum Reprod 2005;20:3178-83.

85. Silberstein T, MacLaughlin DT, Shai I, Trimarchi JR, Lambert-Messerlian G, Seifer DB, et al. Mullerian inhibiting substance levels at the time of HCG administration in IVF cycles predict both ovarian reserve and embryo morphology. Hum Reprod 2006;21:159-63.

86. Gustafson ML, Lee MM, Scully RE, Moncure AC, Hirakawa T, Goodman A, et al. Mullerian inhibiting substance as a marker for ovarian sex-cord tumor. $\mathrm{N}$ Engl J Med 1992;326:466-71.

87. Gustafson ML, Lee MM, Asmundson L, MacLaughlin DT, Donahoe PK. Mullerian inhibiting substance in the diagnosis and management of intersex and gonadal abnormalities. J Pediatr Surg 1993;28:439-44.

88. Chang HL, Pahlavan N, Halpern EF, MacLaughlin DT. Serum Mullerian Inhibiting Substance/anti-Mullerian hormone levels in patients with adult granulosa cell tumors directly correlate with aggregate tumor mass as determined by pathology or radiology. Gynecol Oncol 2009;114:57-60.

89. Dutertre M, Gouedard L, Xavier F, Long WQ, di Clemente $\mathrm{N}$, Picard JY, et al. Ovarian granulosa cell tumors express a functional membrane receptor for anti-Mullerian hormone in transgenic mice. Endocrinology 2001;142:4040-6.

90. Donahoe PK, Clarke T, Teixeira J, Maheswaran S, MacLaughlin DT. Enhanced purification and production of Mullerian inhibiting substance for therapeutic applications. Mol Cell Endocrinol 2003;211:37-42.

91. Teixeira J, Maheswaran S, Donahoe PK. Mullerian inhibiting substance: an instructive developmental hormone with diagnostic and possible therapeutic applications. Endocr Rev 2001;22:657-74.

92. Di Clemente N, Josso N, Gouedard L, Belville C. Components of the anti-Mullerian hormone signaling pathway in gonads. Mol Cell Endocrinol 2003;211:9-14.

93. Josso N, Clemente Nd. Transduction pathway of antiMullerian hormone, a sex-specific member of the TGFbeta family. Trends Endocrinol Metab 2003;14:91-7.

94. Scully RE. Recent progress in ovarian cancer. Hum Pathol 1970;1:73-98.

95. Donahoe PK, Swann DA, Hayashi A, Sullivan MD. Mullerian duct regression in the embryo correlated with cytotoxic activity against human ovarian cancer. Science

\section{9;205:913-5.}

96. Fuller AF Jr, Guy S, Budzik GP, Donahoe PK. Mullerian inhibiting substance inhibits colony growth of a human ovarian carcinoma cell line. J Clin Endocrinol Metab 1982;54:1051-5.

97. Masiakos PT, MacLaughlin DT, Maheswaran S, Teixeira J, Fuller AF Jr, Shah PC, et al. Human ovarian cancer, cell lines, and primary ascites cells express the human Mullerian inhibiting substance (MIS) type II receptor, bind, and are responsive to MIS. Clin Cancer Res 1999;5:3488-99.

98. Stephen AE, Pearsall LA, Christian BP, Donahoe PK, Vacanti JP, MacLaughlin DT. Highly purified mullerian inhibiting substance inhibits human ovarian cancer in vivo. Clin Cancer Res 2002;8:2640-6.

99. Berkenblit A, Cannistra SA. Advances in the management of epithelial ovarian cancer. J Reprod Med 2005;50:426-38.

100. Barbie TU, Barbie DA, MacLaughlin DT, Maheswaran S, Donahoe PK. Mullerian Inhibiting Substance inhibits cervical cancer cell growth via a pathway involving p130 and p107. Proc Natl Acad Sci U S A 2003;100:15601-6.

101. Jemal A, Murray T, Samuels A, Ghafoor A, Ward E, Thun MJ. Cancer statistics, 2003. CA Cancer J Clin 2003;53:5-26.

102. Salom E, Almeida Z, Mirhashemi R. Management of recurrent ovarian cancer: evidence-based decisions. Curr Opin Oncol 2002;14:519-27.

103. Donahoe PK, Fuller AF Jr, Scully RE, Guy SR, Budzik GP. Mullerian inhibiting substance inhibits growth of a human ovarian cancer in nude mice. Ann Surg 1981;194:472-80.

104. Chin TW, Parry RL, Donahoe PK. Human mullerian inhibiting substance inhibits tumor growth in vitro and in vivo. Cancer Res 1991;51:2101-6.

105. Ha TU, Segev DL, Barbie D, Masiakos PT, Tran TT, Dombkowski D, et al. Mullerian inhibiting substance inhibits ovarian cell growth through an Rb-independent mechanism. J Biol Chem 2000;275:37101-9.

106. Fuller AF Jr, Krane IM, Budzik GP, Donahoe PK. Mullerian inhibiting substance reduction of colony growth of human gynecologic cancers in a stem cell assay. Gynecol Oncol 1985;22:135-48.

107. Bakkum-Gamez JN, Aletti G, Lewis KA, Keeney GL, Thomas BM, Navarro-Teulon I, et al. Mullerian inhibiting substance type II receptor (MISIIR): a novel, tissue-spe- 


\section{Obstetrics \& Gynecology Science}

Jang Heub Kim, et al. MIS/AMH: A novel treatment for Müllerian tumors

cific target expressed by gynecologic cancers. Gynecol Oncol 2008;108:141-8.

108. Song JY, Chen KY, Kim SY, Kim MR, Ryu KS, Cha JH, et al. The expression of Mullerian inhibiting substance/antiMullerian hormone type II receptor protein and mRNA in benign, borderline and malignant ovarian neoplasia. Int J Oncol 2009;34:1583-91.

109. Connolly DC, Bao R, Nikitin AY, Stephens KC, Poole $T W$, Hua $X$, et al. Female mice chimeric for expression of the simian virus $40 \mathrm{TAg}$ under control of the MISIIR promoter develop epithelial ovarian cancer. Cancer Res 2003;63:1389-97.

110. Pieretti-Vanmarcke R, Donahoe PK, Szotek P, Manganaro T, Lorenzen MK, Lorenzen J, et al. Recombinant human Mullerian inhibiting substance inhibits long-term growth of MIS type II receptor-directed transgenic mouse ovarian cancers in vivo. Clin Cancer Res 2006;12:1593-8.

111. MacLaughlin DT, Donahoe PK. Mullerian inhibiting substance: a potential nontoxic, naturally occurring therapeutic agent for certain human cancers. In: Jakowlew $\mathrm{SB}$, editor. Transforming growth factor-[beta] in cancer therapy. 1st ed. Totowa: Humana Press; 2008. p.333-54.

112. Nam SW, Jo YS, Eun JW, Song JY, Ryu KS, Lee JY, et al. Identification of large-scale characteristic genes of Mullerian inhibiting substance in human ovarian cancer cells. Int J Mol Med 2009;23:589-96.

113. Pieretti-Vanmarcke R, Donahoe PK, Pearsall LA, Dinulescu DM, Connolly DC, Halpern EF, et al. Mullerian Inhibiting
Substance enhances subclinical doses of chemotherapeutic agents to inhibit human and mouse ovarian cancer. Proc Natl Acad Sci U S A 2006;103:17426-31.

114. Song JY, Jo HH, Kim MR, Lew YO, Ryu KS, Cha JH, et al. Expression of Mullerian inhibiting substance type ॥ receptor and antiproliferative effects of MIS on human cervical cancer. Int J Oncol 2012;40:2013-21.

115. Hwang SJ, Suh MJ, Yoon JH, Kim MR, Ryu KS, Nam SW, et al. Identification of characteristic molecular signature of Mullerian inhibiting substance in human HPV-related cervical cancer cells. Int J Oncol 2011;39:811-20.

116. Sovak MA, Bellas RE, Kim DW, Zanieski GJ, Rogers AE, Traish AM, et al. Aberrant nuclear factor-kappaB/Rel expression and the pathogenesis of breast cancer. J Clin Invest 1997;100:2952-60.

117. Nakshatri H, Bhat-Nakshatri P, Martin DA, Goulet RJ Jr, Sledge GW Jr. Constitutive activation of NF-kappaB during progression of breast cancer to hormone-independent growth. Mol Cell Biol 1997;17:3629-39.

118. Namkung J, Song JY, Jo HH, Kim MR, Lew YO, Donahoe PK, et al. Mullerian inhibiting substance induces apoptosis of human endometrial stromal cells in endometriosis. J Clin Endocrinol Metab 2012;97:3224-30.

119. Borahay MA, Lu F, Ozpolat B, Tekedereli I, Gurates B, Karipcin $S$, et al. Mullerian inhibiting substance suppresses proliferation and induces apoptosis and autophagy in endometriosis cells in vitro. ISRN Obstet Gynecol 2013;2013:361489. 